\title{
Antioxidant and Anti-Inflammatory Effects of NCW Peptide from Clam Worm (Marphysa sanguinea)
}

\author{
Young Ran Park', Chan-II Park' ${ }^{2}$, and Yunjo Soh ${ }^{1,3 *}$ \\ 'Department of Dental Pharmacology, School of Dentistry, Jeonbuk National University, Jeonju 54896, Republic of Korea \\ ${ }^{2}$ Department of Marine Biology and Aquaculture, College of Marine Science, Gyeongsang National University, \\ Tongyeong 52828, Republic of Korea \\ ${ }^{3}$ Department of Pharmacology, School of Pharmacy and Institute of New Drug Development, Jeonbuk National \\ University, Jeonju 54896, Republic of Korea
}

\begin{abstract}
Clam worms (Marphysa sanguinea) are a rich source of bioactive components such as the antibacterial peptide, perinerin. In the present study, we explored the physiological activities of a novel NCWPFQGVPLGFQAPP peptide (NCW peptide), which was purified from clam worm extract through high-performance liquid chromatography. Tandem mass spectrometry (MS/MS) revealed that NCW was a new peptide with a molecular weight of $1757.86 \mathrm{kDa}$. Moreover, NCW peptide exhibited significant antioxidant effects, causing a 50\% inhibition of DPPH radical at a concentration of $20 \mu \mathrm{M}$ without showing any cytotoxicity. These were associated with a reduction in the activity of catalase (CAT), superoxide dismutase (SOD), glutathione peroxidase (GSH-Px), and malondialdehyde (MDA) in LPS-stimulated RAW264. 7 cells. Furthermore, NCW peptide exhibited anti-inflammatory effects in LPS-stimulated RAW264.7 macrophages via inhibition of the abnormal production of pro-inflammatory cytokines including nitric oxide (NO), inducible nitric oxide synthase (iNOS), and cyclooxygenase-2 (COX-2). These anti-inflammatory effects of NCW peptide were associated with the inhibition of interleukin-1 $\beta$ (IL-1 $\beta$ ) and tumor necrosis factor- $\alpha$ (TNF- $\alpha$ ). Our results therefore suggest that this novel NCW peptide with antioxidant and anti-inflammatory effects could be a good therapeutic agent against inflammation-related diseases.
\end{abstract}

Keywords: Novel peptide, clam worm, antioxidant, anti-inflammation

Received: March 26, 2020 Accepted: July 14, 2020

First published online: July 17,2020

*Corresponding author Phone: +82-63-270-4038 Fax: +82-63-270-4037 E-mail:ysoh@jbnu.ac.kr

pISSN 1017-7825 elSSN 1738-8872

Copyright(C) 2020 by The Korean Society for Microbiology and Biotechnology

\section{Introduction}

Inflammation has been well established as a localized response of tissue to irritation, injury, or infection characterized by pain, redness, and swelling. Commonly, inflammation is triggered by the generation of specific cytokines or chemokines and is distinguished by the gathering of leukocytes to the damage site. Lipopolysaccharide (LPS), derived from the outer membrane (OM) of gram-negative bacteria, leads to the activation of reactive oxygen species (ROS) and oxidative stress $[1,2]$. Previous studies have shown that LPS can activate nuclear factor-kappa B (NF- $\mathrm{B})$, a major nuclear transcription factor that controls various inflammatory regulators such as tumor necrosis factor- $\alpha$ (TNF- $\alpha$ ), interleukin- $1 \beta$ (IL- $1 \beta)$, inducible nitric oxide synthase (iNOS) and cyclooxygenase-2 (COX-2) [3, 4].

During inflammation, oxidative stress also leads to high levels of ROS and activation of malondialdehyde (MDA) and decreases production of anti-oxidant enzymes, such as catalase (CAT), superoxide dismutase (SOD) and glutathione peroxidase (GSH-Px) [5]. Clinically, high levels of oxidative damage have been positively associated with cardiovascular diseases, diabetes, and chronic inflammation [6]. Thus, inhibiting levels of inflammatory factors and oxidative stress may help in treating various inflammation-related diseases.

Earthworms have a high density of nutritional content which is of soil-based origin [7]. Recent findings on earthworms have shown them to possess antipyretic, anti-spasmodic, detoxic, diuretic, anti-hypertensive, antiallergic, anti-asthmatic, anti-oxidation, anti-microbial, anti-cancer and anti-inflammation properties [8].

Thus far, antimicrobial peptides have been identified from some Polychaetes species, including Arenicola marina, Perinereis aibuhitensis, and Nereis diversicolor. Lectin (chitin-binding protein) and the antimicrobial peptide arenicin have been extracted from the coelomocytes or fluid of the marine polychaeta lugworm A. marina. Moreover, the antimicrobial peptide perinerin has been purified from the Asian marine clamworm, P. aibuhitensis, and the antimicrobial peptide hedistin was identified from the coelomocytes of N. diversicolor [9]. However, there is relatively little information on the antioxidant capacity and anti-inflammatory activities of the clam worm and its cellular mechanism for modulating inflammation and oxidants in host defense. 
In our previous study, we reported that clam worm extracts have antioxidant and anti-inflammatory effects with treatment of peptidoglycan [10]. Clam worm also exhibited strong antioxidant and anti-inflammatory activities when compared with earthworm extract in LPS-induced RAW264.7 cells [11].

In this study, we investigated whether NCW peptide, a novel bioactive peptide from worm (Marphysa sanguinea) extract, is involved in antioxidant and anti-inflammatory effects in mouse macrophage. To identify NCW peptide from clam worm extract, we used HPLC and MS/MS analysis and isolated the NCW peptide. We found that NCW peptide was a novel peptide extracted from clam worm and there was no cytotoxicity in LPSinduced Raw264.7 cells. Furthermore, our results showed that NCW peptide markedly suppressed the generation of MDA and increased activity of CAT, SOD, and GSH-Px in LPS-stimulated RAW264.7 cells. Moreover, NCW peptide significantly inhibited the activity of pro-inflammatory cytokines such as IL- $1 \beta$ and TNF- $\alpha$ by blocking the NO, iNOS and COX-2 expression in LPS-stimulated RAW 264.7 cells. Thus, these results suggest that NCW peptide may be a new therapeutic candidate to treat a variety of inflammation-related diseases.

\section{Materials and Methods}

Tissue Extraction and Reverse-Phase HPLC

An NCW peptide was isolated from the marine clam worm, Marphysa sanguinea. Adult clam worms ( 200 g) were absorbed in clean, mildly cold, artificial sea water with 2.7-3\% marine salt for $48 \mathrm{~h}$ to remove gastrointestinal metabolites and filth. Clam worms were maintained in frozen state at $-80^{\circ} \mathrm{C}$ by deep freezer (Ilshin Rab Co., Ltd.). Once in a frozen state, the clam worms were added to four volumes of pre-heated $1 \%$ acetic acid (HAc) (1:4, v/v) and boiled for $5 \mathrm{~min}$ to inhibit proteolytic enzyme activity. The boiled tissue was then completely homogenized (Speed \#6, T10 Basic Ultra-Turrax, USA) on wet ice for $5 \mathrm{~min}$. The homogenate was centrifuged (15,000 g, $30 \mathrm{~min}$, $4^{\circ} \mathrm{C}$ ), and the supernatant was stored at $-70^{\circ} \mathrm{C}$ until use. The peptides in the supernatant were then subjected to reverse-phase concentration using a Sep-Pak C18 cartridge (Waters Associates, USA). The active fractions were pooled and further purified by reverse-phase HPLC on a Delta Pak C18 column (Waters Associates) with a linear gradient of $0-60 \%$ acetonitrile containing $0.1 \%(\mathrm{v} / \mathrm{v})$ trifluoroacetic acid over $60 \mathrm{~min}$ at a flow rate of $1 \mathrm{ml} / \mathrm{min}$. The column effluent was detected by its UV absorption at $225 \mathrm{~nm}$, and the absorbance peaks were collected and used for antimicrobial activity analysis after lyophilization.

\section{Mass Spectrometry (MS) and Peptide Sequencing}

Peptide mixtures were analyzed by mass spectrometer (UPLC-Q-TOF) (micrOTOF-Q III, Bruker). The peptides were separated in a column $(\mathrm{C} 18,5 \mu \mathrm{m}, 32 \times 150 \mathrm{~mm})$ and eluted with a linear gradient of $10-45 \%$ solvent $\mathrm{B}(100 \%$ acetonitrile, $0.1 \% \mathrm{FA}$ in water) in Solvent A $(0.1 \% \mathrm{FA}$ in water) at a flow rate of $0.1 \mathrm{ml} / \mathrm{min}$. All MS/MS analyses were carried out using the positive ion mode between $\mathrm{m} / \mathrm{z} 50$ and 2,000. MS/MS ions were analyzed by Data Analysis (4.0) to confirm the peptide sequence. The sequence of the identified peptides was confirmed by BioTool (3.2).

\section{Cell Culture and Treatment of LPS}

RAW264.7 cells were obtained from the American Type Culture Collection (ATCC, USA) and were maintained with Dulbecco's Modified Eagle's Medium (DMEM, Gibco, Waltham, MA, USA) supplemented with 10\% heatinactivated fetal bovine serum (FBS, Gibco), $100 \mathrm{U} / \mathrm{ml}$ penicillin (Gibco), and $100 \mu \mathrm{g} / \mathrm{ml}$ streptomycin (Gibco). The cells were cultured in a humidified atmosphere of $5 \% \mathrm{CO}_{2}$ at $37^{\circ} \mathrm{C}$. For stimulation with LPS, RAW264.7 cells were pre-incubated in the presence or absence of indicated concentrations of NCW peptide for $2 \mathrm{~h}$ in serum-free media. Then, the cells were incubated with LPS $(2 \mu \mathrm{g} / \mathrm{ml})$ PBS for $20 \mathrm{~h}$ in conditioned medium.

\section{DPPH Radical Scavenging Activity}

The DPPH radical scavenging activity was modified by l,1-diphenyl-2-picryl-hydrazyl (DPPH) according to the previously exhibited methods [12]. Briefly, the DPPH reagent was dissolved in methanol for a solution concentration of $80 \mu \mathrm{l} / \mathrm{ml}$. To determine the scavenging activity, $100 \mu \mathrm{l}$ of DPPH reagent was added with $100 \mu \mathrm{l}$ of sample in a 96-well microplate, which was incubated at $37^{\circ} \mathrm{C}$ for $15 \mathrm{~min}$. The absorbance was measured at $517 \mathrm{~nm}$ using a microplate reader, and $100 \%$ methanol was used as a blank (A0). The decrease in absorption of DPPH solution is calculated as follows:

$\%$ of absorption decreased $=(\mathrm{A} 0-\mathrm{A} 1) \times 100 / \mathrm{A} 0$

Vitamin $\mathrm{C}$ was used as a positive control and the antioxidant was evaluated based on this $\mathrm{IC}_{50}$ value. All samples were carried out in triplicate.

\section{MTT Assay}

Cell viability was determined by MTT [3-(4,5-dimethylthiazol-2-yl)-2,5-diphenyltetrazolium bromide] assay. In brief, $5 \times 10^{3}$ cells/well of RAW264.7 cells were incubated with various concentrations of NCW peptide for 24 . Media containing $100 \mu \mathrm{g} / \mathrm{ml}$ of MTT solution were added to cells for $2 \mathrm{~h}$ at $37^{\circ} \mathrm{C}$. The conditioned media were then removed and purple formazan crystals were solubilized with DMSO. The absorbance was determined at $540 \mathrm{~nm}$ using a spectrophotometer and all samples were assayed in triplicate.

\section{Measurements of Antioxidant Activity}

To determine the concentration of released levels of CAT, SOD, GSH-Px, and MDA, RAW 264.7 cells were induced with various concentrations of NCW peptide for $2 \mathrm{~h}$ and treated with LPS $(2 \mu \mathrm{g} / \mathrm{ml})$ for $20 \mathrm{~h}$. The catalase 
activity was analyzed according to the Aebi method [13] and calculated by the change of the absorbance at $340 \mathrm{~nm}$. The amount of SOD (Oxis Research, USA) and GSH-Px (Oxis International, Inc., USA) in cultured medium were quantified according to the manufacturer's instructions, respectively. MDA was determined by the method of Buege and Aus [14]. All samples were assayed in triplicate.

\section{Nitric Oxide (NO) Assay}

The concentration of nitric oxide in the culture supernatant was analyzed using the Griess reagent [15]. In brief, $150 \mu \mathrm{l}$ of the culture supernatant was mixed with $50 \mu \mathrm{l}$ of Griess reagent (1\% sulfanilamide and $0.1 \%$ naphthylethylene diamine in $2.5 \%$ phosphoric acid solution) and incubated at room temperature for $10 \mathrm{~min}$. The absorbance at $540 \mathrm{~nm}$ was measured using a spectrophotometer. Nitrite production in each sample was determined from $\mathrm{NaNO}_{2}$ serial dilution standard curve. All samples were assayed in triplicate

\section{Preparation of Cell Extract}

To prepare whole cell lysates, cells were harvested and homogenized in lysis buffer ( $50 \mathrm{mM}$ Tris- $\mathrm{HCl}, 150 \mathrm{mM}$ $\mathrm{NaCl}, 1 \% \mathrm{NP} 40,0.25 \%$ sodium deoxycholate, $1 \mathrm{mM}$ EDTA, $1 \mathrm{mM} \mathrm{Na} \mathrm{VO}_{4}, 1 \mathrm{mM}$ phenylmethyl-sulfonyl fluoride (PMSF), $1 \mu \mathrm{g} / \mathrm{ml}$ leupeptin, $1 \mu \mathrm{g} / \mathrm{ml}$ pepstatin, $5 \mu \mathrm{g} / \mathrm{ml}$ aprotinin, and $20 \mathrm{mM} \mathrm{NaF}$ ). The suspension was centrifuged for $15 \mathrm{~min}$ and the supernatant was collected as the whole-cell extract.

\section{Western Blot Analysis}

Equal amounts of proteins were separated by 8-10\% sodium dodecyl sulfate-polyacrylamide gel electrophoresis (SDS-PAGE) and transferred to a polyvinylidene difluoride membrane (PVDF). Membranes were blocked with a solution of $5 \%$ non-fat dry skim milk in TTBS at $17^{\circ} \mathrm{C}$ for $1 \mathrm{~h}$, and then primary antibodies were probed for overnight. Horseradish peroxidase-conjugated anti-rabbit or anti-mouse were used as secondary antibodies at $17^{\circ} \mathrm{C}$ for $2 \mathrm{~h}$. Blot images were detected using ECL western blot detection reagent (Amersham Biosciences, USA) and X-ray film.

\section{Measurement of Pro-Inflammatory Cytokines}

To determine the levels of pro-inflammatory cytokines, RAW264.7 cells were pre-incubated with NCW peptide for $30 \mathrm{~min}$ and then stimulated with LPS $(2 \mu \mathrm{g} / \mathrm{ml})$ for $8 \mathrm{~h}$ or $24 \mathrm{~h}$. Concentrations of tumor necrosis factor- $\alpha$ (TNF- $\alpha$ ) and interleukin-1 $\beta$ (IL-1 $\beta$ ) in the culture supernatants were analyzed using a commercially available mouse TNF- $\alpha$ and IL-1 $\beta$ ELISA kit (R\&D Systems, USA) according to the manufacturer's instructions. All samples were assayed in triplicate.

\section{Statistical Analysis}

Statistical analysis was calculated using Prism version 5.0 (GraphPad Software, USA). Data were analyzed using one- or two-way analysis of variance (ANOVA), presented as mean \pm standard deviation (SD). All experiments were repeated three times, and the significant differences between groups were determined at $p<0.05$.

\section{Results}

\section{Identification of the NCW Peptide from Clam Worm (M. sanguinea) Extract Using HPLC}

To identify the role of clam worm extract in antioxidant and anti-inflammatory activity, soluble extracts from clam worm were fractioned using HPLC and MS/MS analysis was used to analyze the peptide sequence. As shown in Fig. 1A, the retention time of clam worm extract was about $23 \mathrm{~min}$ and we identified nine peptides from substrate including NCW, EAV, FDF, LSE, KPF, RST, HYD, FYH, and MGL (Table 1). To determine the antioxidant effects of nine peptides, we performed 2,2-diphenyl-1-picrylhydrazyl (DPPH) assays. The DPPH radical

A

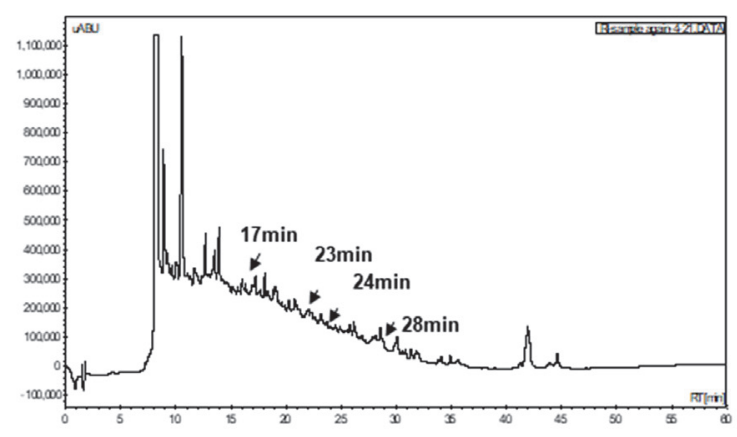

\section{B DPPH assay}

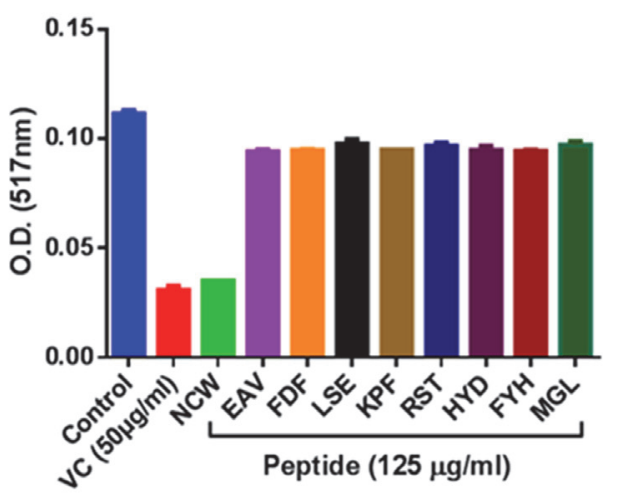

Fig. 1. Identification of NCW peptide from clam worm extracts by high-pressure liquid chromatography (HPLC) and DPPH assay. (A) A typical HPLC of fraction of clam worm. (B) After incubation at $16^{\circ} \mathrm{C}$ for $15 \mathrm{~min}$, the absorbance of final solution was measured at $517 \mathrm{~mm}$ using an ELISA microplate reader. 
Table 1. Identification of peptide using MS/MS.

\begin{tabular}{ccclc}
\hline Fraction & Charge & $\mathrm{m} / \mathrm{z}$ & \multicolumn{1}{c}{ Sequencing } & Calc. mass \\
\hline $17 \mathrm{~min}$ & 2 & 562.78 & MGLVSDLNLY & 1124.56 \\
& 2 & 632.32 & RSTSSLDTRKL & 1263.64 \\
& 3 & 352.17 & FYHGDLRF & 1054.51 \\
& 2 & 505.31 & EAVLHKSLL & 1009.62 \\
& 2 & 604.79 & HYDLFNRFP & 1208.58 \\
$23 \mathrm{~min}$ & 2 & 879.43 & NCWPFQGVPLGFQAPP & 1757.86 \\
$28 \mathrm{~min}$ & 3 & 703.85 & FDFGQPTALFYT & 1406.7 \\
& 2 & 933.47 & LPFSKPALYESEEFPP & 1865.95 \\
\hline \multirow{2}{*}{$28 \mathrm{~min}$} & 2 & 932.98 & & 1864.96 \\
\hline
\end{tabular}

scavenging activity of peptides was compared with that of vitamin $\mathrm{C}$, another antioxidant. The result showed that the radical scavenging activity of NCW peptide was found to be highest in 9 peptides, similar with vitamin C (Fig. 1B). Therefore, we selected NCW peptide for the following study.

Effects of NCW on the Activities of Antioxidant Enzymes

The antioxidant activity of NCW peptide can be considered by its capacity to scavenge stable DPPH free radical. In our preliminary data, it was found that $\mathrm{NCW}$ peptide showed a high $\mathrm{DPPH}$ radical scavenging activity $\left(\mathrm{IC}_{50}\right.$ of $17.48 \mu \mathrm{g} / \mathrm{ml})$ compared to vitamin C $(2.752 \mu \mathrm{g} / \mathrm{ml})$. Biochemical parameters including CAT, SOD, GSH-Px, and MDA levels were examined to further elucidate the antioxidant mechanism of NCW peptide. CAT activity was markedly higher in the 25-50 $\mu \mathrm{M}$ concentrations of NCW peptide than LPS-treated group (Fig. 2A). Next, SOD activity was significantly enhanced in the 5-50 $\mu \mathrm{M}$ concentrations of NCW peptide when compared with the LPStreated group (Fig. 2B). Moreover, GSH-Px activity was markedly increased in the 5-50 $\mu \mathrm{M}$ concentrations of NCW relative to activity in the LPS-treated group (Fig. 2C). MDA levels in LPS-stimulated RAW264.7 were also significantly increased in the control $(p<0.05)$ whereas they decreased significantly upon treatment with NCW at the 5-50 $\mu \mathrm{M}$ concentrations $(p<0.05)$ (Fig. 2D). These results indicate that the response to treatment with high doses $(25$ and $50 \mu \mathrm{M})$ of NCW peptide is more potent than the response to low concentrations $(5 \mu \mathrm{M})$, corresponding with higher catalase activity.

Effect on Cell Cytotoxicity of NCW Peptide on RAW264.7 Cells

The cytotoxic activity of NCW peptide on RAW264.7 cells was analyzed by exposing the cells to various concentrations $(0,5,25$, and $50 \mu \mathrm{M})$ of NCW peptide for $24 \mathrm{~h}$. According to our results, NCW peptide had no significant cytotoxic effects on RAW264.7 cells at the indicated concentrations compared with control (Fig. 3).

A

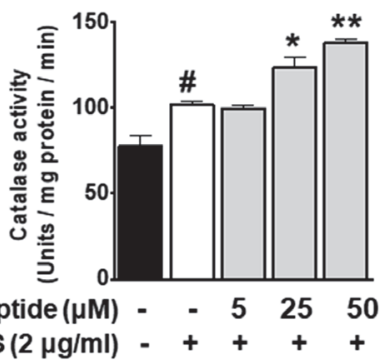

C

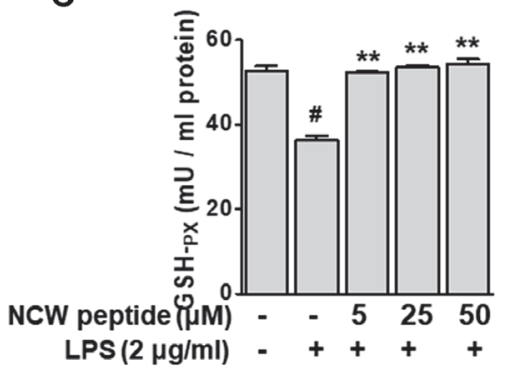

B

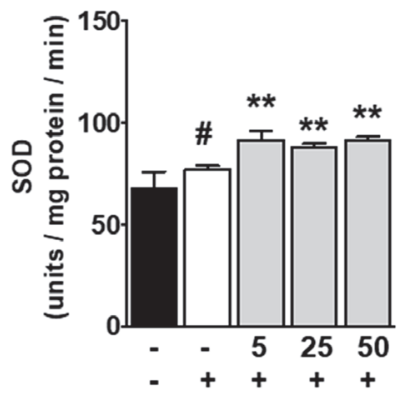

D

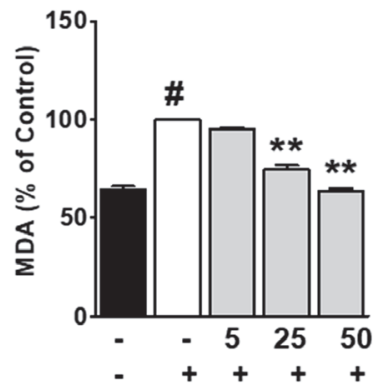

Fig. 2. Effect of NCW peptide on antioxidant enzyme activities in LPS-stimulated RAW264.7 cells. Cells were pre-incubated with various NCW peptide for $2 \mathrm{~h}$ and then incubated with $2 \mu \mathrm{g} / \mathrm{ml}$ of NCW peptide for $20 \mathrm{~h}$. The level of proinflammatory cytokines, (A) catalase (CAT), (B) superoxide dismutase (SOD), (C) glutathione peroxidase (GSH-Px), and (D) MDA were analyzed using cell supernatant. Each value represents mean $\pm \mathrm{SD} .{ }^{*} p<0.05$ as compared with the LPS treatment group (\#). 


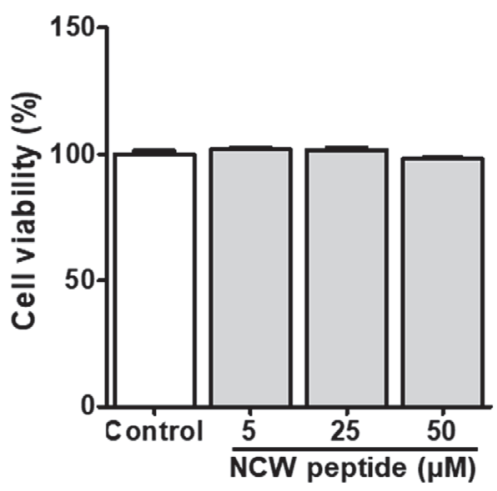

Fig. 3. Cytotoxic effect of NCW peptide on RAW264.7 cells. Cells were treated with or without the NCW peptide at 5, 25 , and $50 \mu \mathrm{M}$ for $24 \mathrm{~h}$, and the cell viability was determined by optimal density at $450 \mathrm{~nm}$ using the MTT assay. Values represent the mean and standard deviation (SD) of triplicate experiments $(n=3)$.

\section{Effects of NCW Peptide on Nitrite Production}

To investigate the anti-inflammatory effect of NCW peptide, we performed the NO assay in the supernatant of RAW264.7 cells. We pretreated cells with or without the NCW peptide (5-50 $\mu \mathrm{M})$ for 30 min before stimulation with $2 \mu \mathrm{g} / \mathrm{ml}$ LPS for $24 \mathrm{~h}$. As shown in Fig. 4, LPS treatment increased NO production approximately eight-fold, whereas treatment with NCW markedly reduced LPS-stimulated NO production in a concentration-related manner. These results suggest that NCW peptide might have anti-inflammatory activity in LPS-stimulated RAW264.7 cells.

Effect of NCW Peptide on Activity Pro-Inflammatory Cytokines and Mediators in LPS-Induced RAW264.7 Cells

To investigate the anti-inflammatory effect of NCW peptide in vitro, RAW264.7 cells were exposed to NCW peptide or LPS and then the quantities of IL- $1 \beta$ and TNF- $\alpha$ were measured in the cultured medium. NCW peptide markedly inhibited the LPS-stimulated IL- $1 \beta$ production in a concentration-dependent manner compared with the LPS-alone group (Fig. 5A). Moreover, NCW peptide significantly blocked the generation of TNF- $\alpha$ in indicated concentrations of NCW peptide compared with LPS-induced RAW264.7 cells (Fig. 5B). These results strongly suggest that NCW peptide can inhibit the secretion of pro-inflammatory cytokines IL- $1 \beta$ and TNF- $\alpha$ in LPS-stimulated RAW264.7 cells.

Effect of NCW Peptide on iNOS and COX-2 Expression in LPS-Stimulated Macrophage RAW264.7 Cells

To find out whether the inhibition of NO generation was caused by the reduced iNOS activity, we examined the expression of iNOS and COX-2 protein by immunoblot analysis. As shown in Fig. 6A, treatment with LPS increased protein expression of iNOS and COX-2 in RAW264.7 cells. However, the increased levels of iNOS and COX-2 were reversed by treatment with NCW peptide at 5-50 $\mu \mathrm{M}$ compared with the LPS-alone group. We also quantitated the intensity of the protein levels using a densitometer in three independent experiments. The NCW peptide significantly decreased both iNOS and COX-2 proteins in LPS-induced RAW264.7 cells (Figs. 6B and 6C). These results implied that NCW peptide can reduce expressions of iNOS and COX-2 level in LPS-induced RAW264.7 cells.

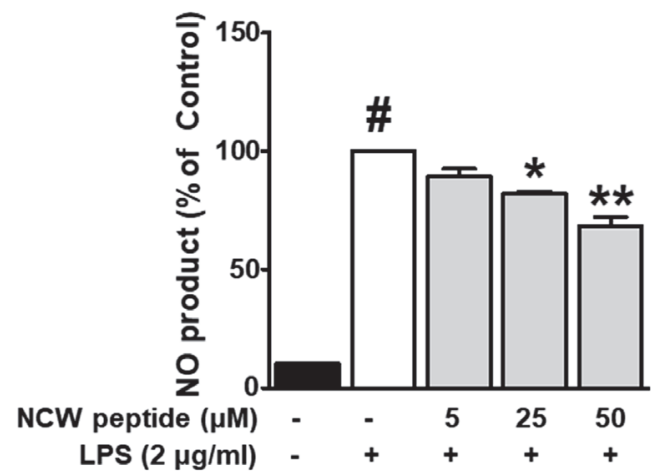

Fig. 4. Effects of NCW peptide on nitrite production in LPS-induced RAW264.7 macrophages. The level of nitrite (NO) was detected using a Griess reaction assay. RAW264.7 cells were pre-treated with various concentrations of NCW peptide for $30 \mathrm{~min}$ and then incubated with $2 \mu \mathrm{g} / \mathrm{ml}$ of LPS for $20 \mathrm{~h} .{ }^{*} p<0.05$ as compared with the LPS alone group (\#). 
A

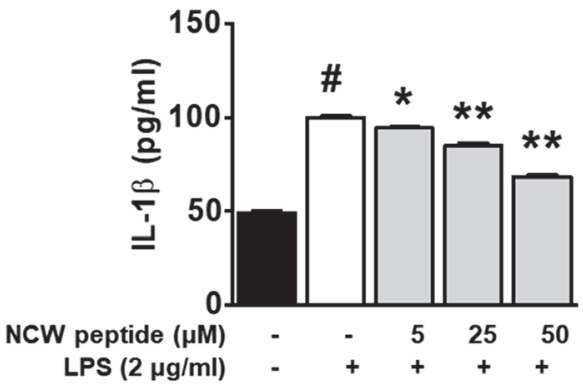

B

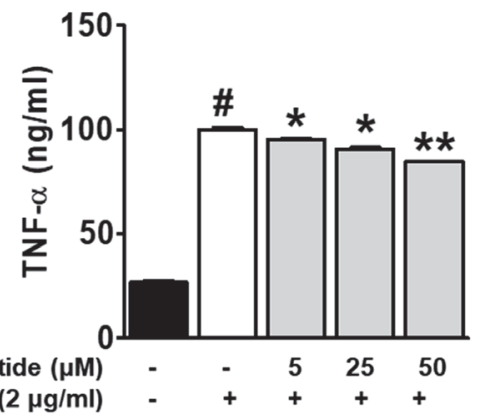

Fig. 5. Effect of NCW peptide on IL-1 $\beta$ and TNF- $\alpha$ level in LPS-stimulated macrophage RAW264.7 cells. RAW264.7 cells were pretreated with or without of NCW peptide at 5, 25, and $50 \mu \mathrm{M}$ for $30 \mathrm{~min}$ and then incubated with $2 \mu \mathrm{g} / \mathrm{ml}$ of LPS for $24 \mathrm{~h}(\mathbf{A})$ and $8 \mathrm{~h}(\mathbf{B})$. The levels of IL- $1 \beta$ and TNF- $\alpha$ were determined by ELISA microplate reader according to the manufacturer's instructions. ${ }^{*} p<0.05$ as compared with the LPS alone group (\#).
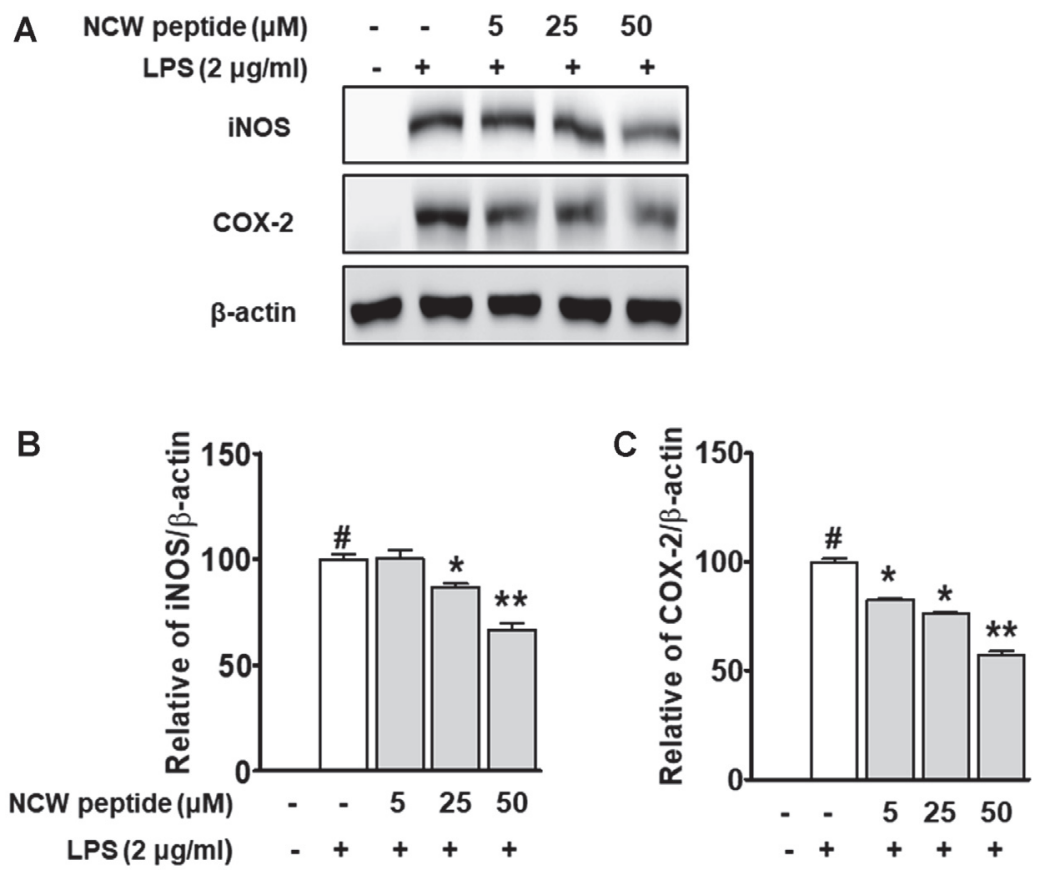

Fig. 6. Effects of NCW peptide on iNOS and COX-2 protein expression in LPS-stimulated RAW264.7 cells. (A) The protein expression levels of iNOS, COX-2, and $\beta$-actin were detected using immunoblot analysis against specific antibodies. Quantification of protein levels was normalized to $\beta$-actin as loading control using a densitometer (Bio-Rad) (B and C). ${ }^{*} p<0.05$ as compared with the LPS-alone group (\#).

\section{Discussion}

Extractions and uses of biological compounds from earthworm have been traditionally utilized in various countries such as China, India, Myanmar, Korea, and Vietnam [16]. There are numerous studies on the antioxidant and anti-inflammation activities of extracts from earthworm $[7,8]$, although very few studies have been done on the sources from clam worm ( $M$. sanguinea). In our previous studies, the extract of clam worm was reported to decrease activities of inflammatory cytokines (TNF- $\alpha$, and IL-1 $\beta$ ), to induce activities of antioxidant enzymes (CAT, SOD and GSH-Px) and to decrease the level of MDA in treatment with peptidoglycan [10]. The extract also exhibited better antioxidant and anti-inflammatory effects than those from earthworm in LPSstimulated RAW264.7 cells [11]. Subsequently, we analyzed the extract of clam worm by using HPLC and the full amino acid sequence was obtained from MS/MS (Table 1) NCW peptide consists of 16 amino acids, N'NCWPFQGVPLGFQAPP-C', a novel peptide that had not been reported yet.

Reactive oxygen species (ROS) can produce activated oxygen such as hydrogen peroxide $\left(\mathrm{H}_{2} \mathrm{O}_{2}\right)$, singlet oxygen, hydroxyl radical, and superoxide anion [17]. Over-production of ROS can generate DNA damage, enzyme inactivation, cellular necrosis and apoptosis, and lipid peroxidation, which are related with other 
pathological diseases including inflammation [18]. Therefore, antioxidants are important molecules that offer protection against the harmful effects of ROS [19].

Pigeolet and colleagues reported that the activities of antioxidant enzymes including CAT, SOD, and GSH-Px, are the most important enzymes for cells in defending against oxidative stress and are essential regulators on detoxification of $\mathrm{O}^{2-}[20,21]$. Endogenous $\mathrm{GSH}$ is a known oxy-radical scavenger and is suggested to play a central function against LPS-stimulated inflammatory response. In addition, MDA production takes place by free radical attacks on the plasma membrane and LPS-stimulated inflammation may lead to the accumulation of MDA. Thus, increased GSH levels lead to reduced MDA generation [22]. In the present study, NCW peptide significantly increased the activity of cellular antioxidant enzymes such as CAT, SOD, and GSH-Px and inhibited the level of MDA in LPS-induced RAW264.7 cells. These results suggest that NCW peptide possesses considerable antioxidant activity and the reduction of MDA may result from the activation of CAT, SOD, and GSH-Px level.

LPS can lead to the generation of pro-inflammatory cytokines, including TNF- $\alpha$, IL-1 $\beta$, and NO, as well as activate iNOS and oxidants [23]. Over-production of TNF- $\alpha$, IL-1 $1 \beta$, and NO plays a central role in chronic inflammatory diseases [24]. Inhibition of the production of inflammatory cytokines and mediators plays as a key role in controlling inflammation, and the suppression of their expression has the therapeutic potential to treat inflammatory diseases [25].

Our findings suggest that the novel peptide, NCW peptide, has antioxidant and anti-inflammation effects by reducing the pre-inflammation cytokines (iNOS, COX-2, TNF- $\alpha$, and IL-1 $\beta$ ) and by increasing the activities of antioxidant enzymes such as CAT, SOD and GSH-Px, and by decreasing the level of MDA. Thus, NCW peptide may be beneficial to human health due to its potential therapeutic application as a novel anti-inflammatory source.

\section{Acknowledgment}

This research was provided for by the project titled 'Development of Antimicrobial Peptide for Animal Feed Additives Using Marine Worms (Polycheata) (20150284), funded by the Ministry of Oceans and Fisheries, Korea (Fishery Commercialization Technology Development Program).

\section{Conflict of Interest}

The authors have no financial conflicts of interest to declare.

\section{References}

1. Jeyaseelan S, Chu HW, Young SK, Worthen GS. 2004. Transcriptional profiling of lipopolysaccharide-induced acute lung injury. Infect. Immun. 72: 7247-756.

2. Tasaka S, Amaya F, Hashimoto S, Ishizaka A. 2008. Roles of oxidants and redox signaling in the pathogenesis of acute respiratory distress syndrome. Antioxid. Redox. Signal. 10: 739-754.

3. Gao Y, Jiang W, Dong C, Li C, Fu X, Min L, et al. 2012. Anti-inflammatory effects of sophocarpine in LPS-induced RAW 264.7 cells via NF-kB and MAPKs signaling pathways. Toxicol. In Vitro 26: 1-6.

4. Zeng KW, Yu Q, Liao LX, Song FJ, Lv HN, Jiang Y, et al. 2015. Anti-neuroinflammatory effect of MC13, a novel coumarin compound from condiment murraya, through inhibiting Lipopolysaccharide-induced TRAF6-TAK1-NF-kappaB, P38/ERK MAPKS and Jak2Stat1/Stat3 pathways. J. Cell. Biochem. 116: 1286-1299.

5. Sontakke, AN, Tare RS. 2002. A duality in the roles of reactive oxygen species with respect to bone metabolism. Clin. Chim. Acta 318: $145-148$.

6. Petersen KS, Smith C. 2016. Ageing-associated oxidative stress and inflammation are alleviated by products from grapes. Oxid. Med. Cell. Longev. 2016: 6236309.

7. Balamurugan M, Parthasarathi K, Ranganathan LS, Cooper EL. 2008. Hypothetical mode of action of earthworm extract with hepatoprotective and antioxidant properties. J. Zhejiang Univ. Sci. B. 9: 141-147.

8. Balamurugan M, Parthasarathi K, Cooper EL, Ranganathan LS. 2007. Earthworm paste (Lampito mauritii, Kinberg) alters inflammatory, oxidative, haematological and serum biochemical indices of inflamed rat. Eur. Rev. Med. Pharmacol. Sci. 11: 77-90.

9. Ovchinnikova TV, Aleshina GM, Balandin SV, Krasnosdembskaya AD, Markelov ML, Frolova EI, et al. 2004. Purification and primary structure of two isoforms of arenicin, a novel antimicrobial peptide from marine polychaeta Arenicola marina. FEBS Lett. 577: 209-214.

10. Kim SW, Sapkota M, Yang M, Li L, Soh Y. 2017. Anti-inflammatory and antioxidant effects of clam worm extract treated with peptidoglycan. Kor. J. Pharmacogn. 48: 187-194.

11. Kim SW, Sapkota M, Li L, Yang M, Park CI, Soh Y. 2016. Anti-inflammatory and antioxidant effects of clam worm extract in macrophage RAW264.7 cells. Kor. J. Pharmacogn. 47: 150-157.

12. Blois MS. 1958. Antioxidant determinations by the use of a stable free radical. Nature 26: 1199-1200.

13. Aebi H. 1984. Catalase in vitro. Methods Enzymol. 105: 121-126.

14. Buege AJ, Aus SD. 1978. Microsomal lipid peroxidation. Methods Enzymol. 52: 302-310.

15. Prasad K, Mantha SV, Muir AD. Westcott ND. 2000. Protective effect of secoisolariciresinol diglucoside against streptozotocininduced diabetes and its mechanism. Mol. Cell. Biochem. 206: 141-149.

16. Popovic M, Hrcenjak TM, Babic T. Kos J. Grdisa M. 2001. Effect of earthworm (G-90) extract on formation and lysis of clots originated from venous blood of dogs with cardiopathies and with malignant tumors. Pathol. Oncol. Res. 7: 197-202.

17. Forrester SJ, Kikuchi DS, Hernandes MS, Xu Q, Griendling KK. 2018. Reactive oxygen species in metabolic and inflammatory signaling. Circ. Res. 16:877-902.

18. Hajjar DP, Gotto AM Jr. 2013. Biological relevance of inflammation and oxidative stress in the pathogenesis of arterial diseases. Am. J. Pathol. 182: 1474-1481.

19. Vaziri ND, Rodríguez-Iturbe B. 2006. Mechanisms of disease: oxidative stress and inflammation in the pathogenesis of hypertension. Nat. Clin. Pract. Nephrol. 2: 582-593.

20. Pigeolet E, Corbisier P, Houbion A, Lambert D, Michiels C, Raes M, et al. 1990. Glutathione peroxidase, superoxide dismutase, and catalase inactivation by peroxides and oxygen derived free radicals. Mech. Ageing Dev. 51: 283-297. 
21. Meghana K, Sanjeev G, Ramesh B. 2007. Curcumin prevents streptozotocin-induced islet damage by scavenging free radicals: a prophylactic and protective role. Eur. J. Pharmacol. 577: 183-191.

22. Kuo MY, Liao MF, Chen FL, Li YC, Yang ML, Lin RH, et al. 2011. Luteolin attenuates the pulmonary inflammatory response involves abilities of antioxidation and inhibition of MAPK and NFkappaB pathways in mice with endotoxin-induced acute lung injury. Food Chem. Toxicol. 49: 2660-2666.

23. Sheeba MS, Asha VV. 2009. Cardiospermum halicacabum ethanol extract inhibits LPS induced COX-2, TNF-alpha and iNOS expression, which is mediated by NF-kappaB regulation, in RAW264.7 cells. J. Ethnopharmacol. 124: 39-44.

24. Franzotti EM, Santos CV, Rodrigues HM, Mourao RH, Andrade MR, Antoniolli AR. 2000. Anti-inflammatory, analgesic activity and acute toxicity of Sida cordifolia L. (Malva-branca). J. Ethnopharmacol. 72: 273-727.

25. Park JY, Cho HY, Kim JK, Noh KH, Yang JR, Ahn JM, et al. 2005. Chlorella dichloromethane extract ameliorates NO production and iNOS expression through the down-regulation of NF kappa B activity mediated by suppressed oxidative stress in RAW 264.7 macrophages. Clin. Chim. Acta 351:185-196. 